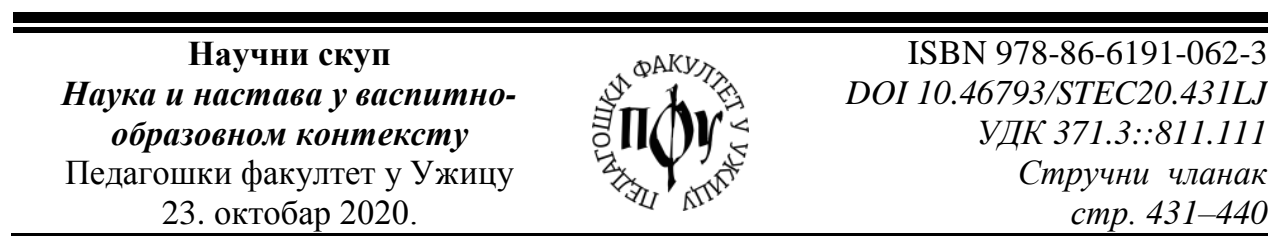

Gordana M. Ljubičić ${ }^{*}$

University of Kragujevac, Faculty of Education Užice

\title{
WHY SHOULD ORAL PRESENTATIONS BE INTRODUCED IN FOREIGN LANGUAGE TEACHING AT TEACHER TRAINING FACULTIES?
}

\begin{abstract}
The students of the Faculty of Education of Uzice have the English language classes during four semesters at their initial studies, that is, during the first and the third year, and again at their master studies. During the first year they mainly develop their grammatical and linguistic competences by reading and translating the texts whose topics relate to their future profession. As the groups of students are rather large there is not much time left for developing their oral skills. This problem is, to some extent, overcome during the third year of studies when the groups become smaller and the teacher is able to dedicate more time to developing speaking skills in the class. A very good speaking task is the introduction of oral presentations. The topics are carefully chosen to arouse students' interests and to make them want to engage in this kind of activity. The paper discusses the advantages and the weak points of this kind of oral tasks at the university level studies.
\end{abstract}

Keywords: English language, oral presentations, learning task, topic, advantages, weak points.

\section{THE IMPORTANCE OF COMMUNICATIVE APPROACH IN LEARNING A FOREIGN LANGUAGE}

Although foreign language learning implies developing four basic language skills, namely, listening, speaking, reading and writing, since 1970's the emphasis has been put on communication which is considered to be the fifth language skill. So, nowadays, the most widely accepted approach in foreign language learning is the Communicative Approach or Communicative Language Teaching (CLT) that puts emphasis on the importance of using real language situations in order to help learning take place. So, instead of developing only the grammatical/linguistic competence of the students, the Communicative Approach aims at developing their

* gordanalj.ue@gmail.com 
Ljubičič, G.: Why Should Oral Presentations be Introduced in Foreign Language...

Научни скуп „Наука и настава у васпитно-образовном контексту” • стр. 431-440

competence to communicate in the target language (communicative competence), with an enhanced focus on real-life situations.

One of the driving forces behind this communicative approach to language teaching is the socio-cultural theory of language acquisition that comes, in part from the writings of Levi Vygotsky. Vygotsky wrote that "all learning takes place as a result of social interaction. Knowledge, therefore, is a construct to be pieced together through an active process of involvement and interaction with the environment" (in Schcolnik, Kol, Arbarbanel, 2006: 12). Duffy and Cunningham note that learning is a "social, communicative and discursive practice inexorably grounded in talk" (Duffy \& Cunningham 1996, in Schcolnik, Kol, Abarbanel, 2006: 17). Enabling learners to use the language they are learning in meaningful activities is considered to be one of the most important postulates of socio-cultural theory. As socio-cultural theorists see language as a social phenomenon, the only way for students to improve as L2 learners is if they are allowed to use the language they are learning in communication with other people. Students who are not given the chance "to interact with other members of the discourse community remain outside the language community, and therefore fail to learn the language" (Apple, 2006: 286).

According to Jack C. Richards, the core assumptions of current communicative language teaching are:

1. Second language learning is facilitated when learners are engaged in interaction and meaningful communication.

2. Effective classroom learning tasks and exercises provide opportunities for students to negotiate meaning, expand their language resources, notice how language is used, and take part in meaningful interpersonal exchange.

3. Meaningful communication results from students processing content that is relevant, purposeful, interesting, and engaging.

4. Communication is a holistic process that often calls upon the use of several language skills or modalities (2006: 21).

\section{TEACHING FOREIGN LANGUAGES AT THE TERTIARY LEVEL OF EDUCATION}

Although the English language is considered to be the lingua franca of the world of today, and although it has been studied throughout the whole of primary and secondary education in Serbia as a compulsory school subject, since 1997 the students at tertiary level (and hare we mean the students of the Faculty of Education) still have difficulties in expressing themselves and communicating with others in this worldwide language. The reason can be their prior knowledge (or in fact, the 
Ljubičič, G.: Why Should Oral Presentations be Introduced in Foreign Language...

Научни скуп „Наука и настава у васпитно-образовном контексту” • стр. 431-440

lack of it), but we, as university teachers, can do very little to rectify the defficiences of the time lost. All we can do is try new approaches and develop new techniques and strategies that will encourage the students to use the real language in as realistic situations as possible. However, all foreign language teachers know how hard and sometimes impossible it is to provide real life situations and particularly to avoid altogether the use of students' mother tongue in a foreign language classroom. That is why the choice of the right language tasks and exercises is so important. One of the language tasks that deffinitely encourages the use of foreign language in a language classroom is the introduction of oral presentations.

\section{WHY USE ORAL PRESENTATIONS IN A FOREIGN LANGUAGE CLASSROOM?}

Oral presentation is the process of presenting a topic to an audience. It is typically a demonstration, introduction, lecture or speech meant to inform, persuade, inspire, motivate or present a new idea or product. Ming defined an oral presentation as "(...) partly spoken, partly visual form of communication" (2005: 118), and it is normally limited in time and occurs in an organized setting.

Why is oral presentation suitable and even compulsory for university students? It has been observed that EFL students show poor achievement in using and controlling the foreign language communication in the classroom, which may be explained by the lack of their competence in that language. On the other hand, it can be argued that not all the students of all the faculties have the same need for using oral expression in the same degree. It is only partly true. In nowadays world all students, both undergraduates and post-graduates, will sometimes find themselves in a situation to present in a foreign language, English in the first place. For the students of teacher training faculties oral expression is one of the foundations of their future profession and the situation with which they will have to cope every day in their work careers. Many students of teacher training faculties already have an impressive, so-called, passive knowledge of a foreign language, but when the time comes, they are, for some reason, unable or unwilling to use that language in oral communication with other people involved. The only way to overcome these difficulties is to make students talk and use foreign language more often in a class during their studies. But, because the groups of students are sometimes very large, and the class time is limited, the teacher is faced with the impossibility of giving every student a chance to speak during every lesson. Sometimes, some students do not say anything during the whole school year. It is partly the fault of the teacher, but more of the learning circumstances. Students, whose knowledge of a foreign language is not very good, find it extremely difficult to start talking about any topic out of the blue, without a previous preparation. If they are forced to do that, they respond abruptly and find themselves in a state of shock, or simply remain silent and the point of communication is lost. That is why, the introduction of carefully chosen 
Ljubičič, G.: Why Should Oral Presentations be Introduced in Foreign Language...

Научни скуп „Наука и настава у васпитно-образовном контексту” • стр. 431-440

topics for oral presentations and skillful scaffolding by the foreign language teacher are of the outmost importance at the tertiary level of studies.

\section{THE BENEFITS OF ORAL PRESENTATIONS}

Oral presentation has its benefits and its weak points. However, the benefits certainly outnumber the weak points, so the foreign language teacher must never give up trying to involve this kind of activity in his teaching. We will mention some of the benefits of oral presentations, although the list is not, and cannot be, definite:

1) We have already mentioned that oral presentation is a student-centered activity. As Wallace said "most teaching at the university was earlier limited to giving formal lectures, however, nowadays it attempts to involve actively the students in the learning process" (2004: 5). That is, instead of listening to the lectures given by the teacher who is standing motionless in front of the class, the students are now urged to take the initiative and to present in front of an audience, either alone or in co-operation with other students. So, the emphasis shifts from the teacher to a student, and the student becomes the center of the instructional situation. "Presentations are one of the few times in the language classroom that the students themselves have direct control of both the content and the flow of the classroom" (Apple \& Kikuchi, 2007: 286). So, presentations have been shown to encourage students to become active and autonomous learners.

2) Oral presentation activates the use of all four language skills. This is very important for all students, but especially for the students of teacher training faculties. At the Faculty of Education in Uzice, the students have the English language classes during four semesters: the first and the second semester of the first year, and the fifth and the sixth semester of the third year of their initial studies. During the first year, most of the foreign language teaching is aimed at rewieving the grammar points and at reading and translating the ESP texts connected with students' future profession. Because the groups of students are rather large, little time is dedicated to speaking skills. But, during the third year of studies, the groups become smaller and the students are ready to start developing their speaking skills to a greater extent. This is the right moment for the introduction of oral presentations. Although in oral presentations speaking is the most important language skill, the other three language skills are also required. In order to take notes or prepare reminders for what they are going to say students must use their writing skills. Reading skills are also important because students have to read all the material collected from different sources, and, finally, if they want to go through different audio sources or hear the questions posed by the audience after the presentation they must develop their listening skills. So, oral presentations develop all the language skills needed for correct and sucessful communication. 
Ljubičič, G.: Why Should Oral Presentations be Introduced in Foreign Language...

Научни скуп „Наука и настава у васпитно-образовном контексту” • стр. 431-440

3) Oral presentations are task-oriented. A language task is a more authentic way of practicing English than a simple and guided speaking drill. Carefully chosen tasks expose students to real-life situations and to real language. As Thornbury puts it: "Speaking tasks that have no relation to real-life language use are poor preparation for autonomy" (2005: 91).

4) Oral presentations do not only develop the knowledge of a foreign language, but knowledge in general. The value of oral presentations exceeds the borders of the language classroom. In order to present well, the students must make effort to read and learn as much about the topic as possible, and to use all valid information in the best way they can in their presentation. If they do so, their presentation will be successful, and they will be rewarded by the approval of their teachers and peers.

5) Successful oral presentation improves students' motivation, develops their confidence and self-esteem. They receive an immediate feedback and, for students, future teachers, that immediate feedback is very important because it shows them to what extent they are prepared for their future profession. They understand what teaching really is and how important, but also difficult, it is to maintain the audience's attention and respect.

6) Oral presentation is a very demanding and complex task which requires careful guiding by the teacher and interaction with other members of the group. If any component in this teacher-presenter-audience chain fails, the presentation will fail, too. That is why we must repeat that this type of task is very important for the students future teachers, for whom the organization of the class work and classroom management is essential.

7) Through oral presentations students improve their IT skills, learn how to use computer in their work, how to use different programmes and applications to design presentations, and also how to shape their presentation. They have to master the use and incorporation of different video material and different visual aids in their talk. The students have to learn how to start their talk, how to choose the slides and decide on their number, and also how to choose the text which is to be put on the slides. They have to decide on the way to carry out their presentation, that is, to either do everything on their own, without any help, if possible, or to ask someone from the group to assist them in presenting.

8) Oral presentations teach students good organization skills. They teach them to be time-aware, to divide the time meant for a presentation well, to have the introduction, the main part and the conclusion. The students must not exceed the time limit given for any of these parts. The length of presentation is also very important: if it is too short, it can not cover all the aspects of the topic, and a too long presentation will certainly bore the students.

9) Oral presentation makes presenters pay attention to their posture, voice, gestures and interaction with the audience. The presenters should avoid being 
Ljubičič, G.: Why Should Oral Presentations be Introduced in Foreign Language...

Научни скуп „Наука и настава у васпитно-образовном контексту” • стр. 431-440

hesitant or losing control. In a study by Otoshi and Heffernan learners identified the following as important when making oral presentations: 1. clarity of speech and voice quality 2. correctness of language 3. interaction with the audience (2008: 65). That, again, is something that students future teachers will deffinitely need in their future work.

\section{WHAT ARE THE WEAK POINTS OF ORAL PRESENTATIONS?}

Beside obvious advantages, oral presentations have certain restrictions ans weak points, too. These can be related to the topic itself, to the personality of the presenter and to some technical details.

1) It is very important to know how to choose the right topic for oral presentation. Choosing the right topic requires careful thinking on the part of the language teache. The topic must be relevant and useful for the particular group of students. It should broaden their knowledge and must be interesting enough to engage students in further discussion. It should not be too familiar to the students, but not entirely unknown to them, either. At the tertiary level of studies, the topics should be more academically defined and good for developing the students thinking skills. Inappropriate or uninterested topics will certainly ruin any presentation. Some of the topics that could be used in oral presentations with the students of teacher training faculties are the following:

a) The Beginnings of School Education in Serbia;

b) The Life and Work of Dositej Obradovic and Vuk Karadzic;

c) School in Nature;

d) Inclusive Education and How to Help Children with Special Needs;

e) How to Spot Gifted Children;

f) Boarding Schools- Reasons For and Against;

g) Montessori Approach;

h) Using Stories in Work with Pre-School and Primary School Children;

i) Why is Music Important in Work with Children?;

j) Nursery Classroom Organization, etc.

2) When the topic is chosen, the main difficulty is how to collect the material and what sources to use. Here, the help of the teacher is necessary. Of course, the main source is always the Internet. But what do most students do? They simply copy the facts from the Internet, and put the whole text on the slides without changing a word of it or doing any necessary adaptation. They often do not look up the new 
Ljubičič, G.: Why Should Oral Presentations be Introduced in Foreign Language...

Научни скуп „Наука и настава у васпитно-образовном контексту” • стр. 431-440

words in the dictionary. Instead, they try to memorize long and complicated sentences, and very often fail. As King states: "The problem for most EFL presenters is rote memorization of text directly copied from written sources" (2007: 16). In this case, mistakes will certainly occur and the presenter will lose control over his presentation. As the result, the audience will soon become inattentive or disrespectful.

3) The teacher certainly has to decide how much to interfere with the presentation. Very often, the teacher is in two minds: whether to correct the errors on the spot, the moment they are made, or to leave the presentation go as it goes and to interfere after it is finished. If the teacher's decisions are not right the final result may be the disappointed presenter and the dissatisfied audience. The common attitude will be that the time of the class has been wasted and that the students have gained nothing from such a presentation.

4) As Ross (2007) puts is, many teachers find oral presentation a timeconsuming activity with little or no pedagogical value. This may be partially true, but, again, the problem here is, as Sundrarajun \& Kiely rightly observe "that such presentations have not been properly scaffolding, which is the first precondition for a presentation to be effective" (2010: 105).

5) Teachers are often against this type of classroom activity because they think that oral presentation is one man's work, an activity that does not engage the whole class, so most learners do not benefit from it. This may be true, so, perhaps, the time dedicated to this type of classroom activity should be limited.

6) Oral presentations are not a spontaneous talk. Most people probably think that oral presentation is in no way different from a spontaneous talk heard every day in a language classroom. Nothing can be further that that. According to Harmer oral presentations are not "designed for informal spontaneous conversations; because they are prepared, they are more "writing like", which is good for fluency and for avoiding hesitation, gaining time, etc.” (2007: 351).

7) Many students find oral presentations scary because they feel that their knowledge of a language is not satisfactory, and that they, as Jordan puts it "lack the core fluency" (1997: 203). This definitely is true in some cases, so, maybe, the solution might be to first give oral presentations only to those students whose knowledge of the foreign language is satisfactory or very good, and let others be mere listeners. But, the thing is, excellent students are already excellent and do not need more practice, while the weak ones do not acquire much from listening to other people's oral talk. This is the weakness of oral presentation that is hard to overcome. Many students do not want to do oral presentations because they feel shy and embarrassed in front of the audience. King pointed out that "oral presentations are usually a face-threatening activity" (2002: 412). In such cases teacher can just leave the things as they are and not push the students until they are ready to try. 
Ljubičič, G.: Why Should Oral Presentations be Introduced in Foreign Language...

Научни скуп „Наука и настава у васпитно-образовном контексту” • стр. 431-440

8) Sometimes, technical equipment and the use of visual aids make it difficult for the students to present well. Very often, different problems arise: equipment does not work well, the students are not skilled enough or not trained enough to use certain applications or programmes, they do not know how to make and design a presentation and cannot decide what amount of material to put on the slides. Sometimes the lack of visual material makes presentation dull. In general, visual aids are very important in oral presentations because "they provide support for both the speakers and listeners during presentation, which can help to reduce stress and make the presentation more successful" (Lambert, 2008: 87).

9) Every presentation should be followed by a discussion and by evaluation given by the teacher himself. If that is missing, the point of the task is lost. The teacher should encourage students to ask relevant questions and to express their opinions. If there is no discussion, the presenter will be unaware of what he had done wrong and of the impression that his presentation had made on the others from the class. Giving a feedback to the presenter means that the others were listening and that they are appreciating the presenter's hard work. Evaluation given by the teacher is important both for the presenter and for the next participants to whom his remarks should be the guidelines.

\section{CONCLUSION}

Oral presentation is a task, very often used in a foreign language classroom, that puts emphasis on speaking. Speaking is a foreign language skill without which a successful communication cannot happen. At the tertiary level of studies, oral presentation is very important as a preparation for future profession and development, especially for the students, future teachers. Through oral presentations they learn how to compose their speech, how to address the audience, how to initiate and hold its attention and how to evaluate what they have heard. Oral presentation is a complex task and sometimes very hard to perform in a group of students whose prior foreign language knowlegde is not good. Still, the benefits of good oral presentation surpass its weak points, and the foreign language teacher has to do his best to make this language task applicable and successful in his language classroom.

\section{References}

Apple, M. (2006). Language Learning Theories and Cooperative Learning Techniques in the EFL Classroom. Doshisha Studies in Language and Culture, 9(2), 277-301.

Apple, M. \& Kikuchi, K. (2007). Practical PowerPoint Group Projects for the EFL Classroom. The JALT CALL Journal, 3(3), 110-122, 
Ljubičič, G.: Why Should Oral Presentations be Introduced in Foreign Language...

Научни скуп „Наука и настава у васпитно-образовном контексту” • стр. 431-440

Duffy, T. \& Cunningham, D. (1996). Constructivism: Implications for the design and delivery of instruction. New York: MacMillan.

Harmer, J. (2007). The Practice of English Language Teaching. Harlow: Longman.

Jordan, Robert, Richard (1997). English for Academic Purposes. Cambridge: Cambridge University Press.

King, J. (2002). Preparing EFL learners for Oral Presentations. Dong Hwa. Journal of Humanistic Studies, 4, 401-418.

Lambert, I. (2008). Assessing Oral Communication: Poster Presentations. Language Research Bulletin ICU, 23, 1-13.

Ming, Xian Zhu (2005). Developing Oral Presentation Skills in ELT Classroom. CELEA Journal, 28(2), 118.

Otoshi, J. \& Heffernen, M. (2008). Factors predicting effective oral presentations in EFL classrooms. Asian EFL Journal, 10(1), 65-78.

Richards, C. Jack (2006). Communicative Language Teaching Today. Cambridge: Cambridge University Press.

Ross, E. (2007). Are oral classrooms presentations necessary? Insights into TEFL. Retrieved August 20, 2018 from the World Wide Web htpp://insights-intotefl.blogspot.com/2007/07.

Schcolnik, M., Kol, S. \& Arbarbanel, J. (2006). Constructivism, in Theory and in Practice English Teaching Forum, 44(4), 12-20.

Sundrarajun, Chutamas \& Kiely, R. (2010). The Oral Presentation as a Context for Learning and Assessment. Innovation in Language Learning and Teaching, 4(2), 101-117.

Thornbury, S. (2005). How to Teach Speaking. Harlow. England. Pearson Education.

Wallace, J. M. (2004). Skills in English (2nd Ed.). Cambridge: CUP. 
Ljubičič, G.: Why Should Oral Presentations be Introduced in Foreign Language...

Научни скуп „Наука и настава у васпитно-образовном контексту” • стр. 431-440

Гордана М. Љубичић

Универзитет у Крагујевцу, Педагошки факултет у Ужицу

\section{ЗАШТО ТРЕБА УВЕСТИ ГОВОРНЕ ПРЕЗЕНТАЦИЈЕ У ПРЕДАВАЫА СТРАНОГ ЈЕЗИКА НА УЧИТЕЉСКИМ ФАКУЛТЕТИМА}

\section{Резиме}

Студенти Педагошког факултета у Ужицу имају наставу страног језика током четири семестра на основним студијама, односно током прве и треће године студија, и поново на мастер студијама. Током прве године они углавном развијају своје граматичке и говорне компетенције читајући и преводећи текстове чији се садржај односи на њихову будућу професију. Пошто су групе студената углавном велике, не остаје много времена за практиковање њиховог усменог изражавања на страном језику. Проблем се донекле превазилази током треће године студија када групе постају мање и када је наставник у могућности да посвети више времена развоју говорних вештина у разреду. Веома добра вежба у овом смислу је увођење говорних презентација. Теме се брижљиво бирају да потстакну интересовање студената и њихову жељу да се укључе у ову врсту активности. У раду се разматрају предности и слабости овакве врсте говорних вежби на напредном, универзитетском нивоу студирања.

Кључне речи: енглески језик, усмене презентације, задаци учења, теме, предности, недостации. 